\title{
Statistical study of four years of urinary infections (UTI) related to urethral catheter in our intensive care unit (ICU)
}

\author{
R Fernández Fernández*, ME Yuste Ossorio, O Moreno Romero, M Muñoz Garach \\ From ESICM LIVES 2015 \\ Berlin, Germany. 3-7 October 2015
}

\begin{abstract}
Introduction
UTI is the most common nosocomial infection, accounting for 23 to $30 \%$ of all infections acquired during hospitalization, with a prevalence of $2 \%$. Increases hospital stay by an average of 4 days, with a consequent increase in hospital costs. Mortality is low and is particularly associated with secondary bacteremia, which occurs from 0.5 to $4 \%$ of these patients. Bladder catheterization (CV) is the most influential factor for developing an UTI. Approximately $75 \%$ of UTIs, affect patients that have required catheterization. Through the application of some of medical and sanitary steps,UTI may decrease about $30 \%$, infectious complications of bladder catheterization.
\end{abstract}

\section{Objectives}

Describe and evaluate the evolution of UTI associated with urethral catheter over 4 years, in a 18-bed ICU.

\section{Methods}

Patients admitted to our ICU 01.04.2011-01.04.2015. Only included patients admitted for more than 24 hours. Followed until ICU's discharge. Statisical parameters: rates / 100 patients (total 4198), / 100 catheterized (2340), incidence density (ID)/ 1000 days of stay (17575 days) , /1000 urinary catheter days (11824). Data from National Nosocomial Infections Surveillance (ENVIN).

\section{Results}

01.04.11-01.04.12, 7 UTIs. Rate: 0.68 / 100 patients; 1.29 / 100 catheterized. ID: $1.45 / 1000$ days of stay; 2.11/1000 catheter days. Microorganisms: E. Coli, K. pneumoniae.

71.43\% sepsis, $85.71 \%$ treated with antibiotics (atb).

Hospital Universitario San Cecilio, Unidad Cuidados Intensivos, Granada, Spain

(c) 2015 Fernández Fernández et al.; This is an Open Access article distributed under the terms of the Creative Commons Attribution License (http://creativecommons.org/licenses/by/4.0), which permits unrestricted use, distribution, and reproduction in any medium, provided the original work is properly cited.
01.04.12-01.04.13, 9 UTIs . Rate: $0.83 / 100$ patients, 1.54/ 100 catheterized. ID: $1.81 / 1000$ days, 2.58/1000 catheter days. Germ: P. Aeruginosa. Sepsis $77.78 \%$, atbs $88.89 \%$.

01.04.2013-01.04.2014, 13 UTIs. Rate: $1.15 / 100$ patients, 2.08/100 catheterized.

ID:2.66/ 1000 days; 3.81/ 1000 catheter days. Germs: C. glabrata, E. coli. Sepsis $23.08 \%$, atbs $46.15 \%$.

01.04.2014-01.04.2015, 15 UTIs. Rate: 1.56/100 patients, $2.53 / 100$ catheterized.

ID:3.56/ 1000 days, 4.91/1000 catheter days.Germs: E. faecium. Sepsis $73.33 \%$, atbs $86.67 \%$.

Spain, last year. Rate:2.52/ 100 patients, 3.44/ 100 catheterized. DI: 3.33/ 1000 days,

3.91/1000 catheter days. Germ: Acinetobacter. Sepsis $63.74 \%$, atbs $82.06 \%$.

We are below the national's rate and ID catheter-associated UTI. This is in relation to: exclusive probing to patients who require it and to sterile conditions in which the maneuver is performed. But our figures have worsened over the years, it is necessary to emphasize in our ICU the most important points again because, as demonstrated in this study,UTIs very often determine sepsis. We treat these ITUs with atbs quite often.

\section{Grant Acknowledgment}

Dra. Yuste

Published: 1 October 2015

Reference

1. [http://hws.vhebron.net/envin-helics/].

\section{Conclusions}


doi:10.1186/2197-425X-3-S1-A892

Cite this article as: Fernández Fernández et al:: Statistical study of four years of urinary infections (UTI) related to urethral catheter in our intensive care unit (ICU). Intensive Care Medicine Experimental 20153 (Suppl 1):A892.

Submit your manuscript to a SpringerOpen ${ }^{\circ}$ journal and benefit from:

- Convenient online submission

- Rigorous peer review

- Immediate publication on acceptance

- Open access: articles freely available online

- High visibility within the field

- Retaining the copyright to your article

Submit your next manuscript at $\gg$ springeropen.com 